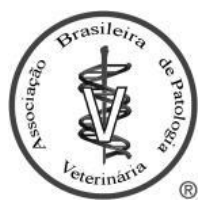

DOI: 10.24070/bjvp.1983-0246.v12i3p123-127

Case Report

\title{
Tremorgenic syndrome in suckling lambs due to poisoning by Ipomoea asarifolia
}

\author{
Givaldo B. Silva Filho ${ }^{1}$, Hisadora A. S. Chaves $^{1}$, Juceli S. Oliveira ${ }^{1}$, José R. P. Santos ${ }^{2}$, João P. G. \\ Silva $^{2}$, Marcela F. Mota $^{2}$, José A. S. Rocha ${ }^{2}$, Joaquim Evêncio Neto ${ }^{2}$, Fábio S. Mendonça ${ }^{2 *}$ \\ ${ }^{1}$ Programa de Pós-Graduação em Medicina Veterinária, Universidade Federal Rural de Pernambuco (UFRPE), Rua Dom Manoel de Medeiros, s/n, Dois \\ Irmãos, Recife, PE 52171-900, Brasil. \\ ${ }^{2}$ Laboratório de Diagnóstico Animal, Universidade Federal Rural de Pernambuco (UFRPE), Rua Dom Manoel de Medeiros, s/n, Dois Irmãos, Recife, PE \\ 52171-900, Brasil. \\ Corresponding author: fabio.mendonca@pq.cnpq.br
}

Submitted September, 29 ${ }^{\text {th }} 2018$, Accepted October, $21^{\text {th }} 2018$

\begin{abstract}
The aim of this study was to describe the clinical, pathological and epidemiological aspects of an outbreak of tremorgenic syndrome in suckling lambs associated to Ipomoea asarifolia poisoning occurred in the metropolitan region of Recife, northeastern Brazil. Eight suckling Dorper lambs presented clinical signs after their mothers being kept in pasture invaded by I. asarifolia. Sixty percent of adult sheep, including lactating ewe, only exhibited engorged episcleral vessels. The suckling lambs exhibited neurological signs, such as head and neck tremors, dysmetria, wide-based stance, uncoordinated gait, unusual standing and imbalance followed by falls. These signs became more evident when the animals were forced to move. No gross lesions were found in a necropsied lamb that had died spontaneously. The histological findings were axonal spheroids in the cerebellum granular layer and numerous necrotic neurons in the cerebral cortex and cerebellum molecular layer. This study demonstrates that Ipomoea asarifolia causes tremorgenic syndrome. The toxin is eliminated through milk and suckling lambs exhibit a greater susceptibility compared to adult animals.
\end{abstract}

Key words: toxic plant, ruminant, neurological disease, sheep, tremorgenic toxin, milk.

\section{Introduction}

The ginger-leaf morning glory, Ipomoea asarifolia (Convolvulaceae), is an herbaceous plant with cordate base leaves and purplish pink flowers (1). It is widely distributed in the north and northeast Brazil $(4,11)$, especially close to rivers and lakes with highly saline soil $(4,16)$. When found in grazing areas of ruminants, it can cause outbreaks of poisoning, especially during prolonged dry seasons when there is shortage of forage $(2,11)$. I. asarifolia belongs to the group of tremorgenic plants and its ingestion causes a syndrome characterized by tremors $(6,8)$. It is an important toxic plant in northeastern Brazils' affecting the central nervous system of ruminants (16). Outbreaks mainly occur in sheep, especially young animals, but goats, cattle and buffaloes may also be affected $(1,4,11,16)$. Experimental poisoning has been demonstrated in sheep, goats, cattle, buffaloes and rodents $(2,6,17,19)$.

Tremors over the entire body, especially the head and neck are the most evident clinical sign in poisoned sheep, which intensify when the animals are stimulated to move (13). Affected ruminants may suffer falls in unusual positions, followed by pedaling movements and difficulty returning to the upright position $(11,12)$. At rest, the main clinical signs are staggering gait, wide-based stance and ataxia $(3,5)$. In most cases, no gross and histological lesions are observed, although some animals with prolonged clinical signs have exhibited neuronal degeneration, the loss of Purkinje cells and axonal spheroids in the cerebellum granular layer $(1,7)$. For producers, economic losses are related to the death of 
severely affected animals or discard due to irreversible conditions (16).

The aim of the present study was to characterize clinical and pathological findings of an outbreak of poisoning by Ipomoea asarifolia in suckling lambs in the metropolitan region of Recife, Brazil.

\section{Case Report}

This study was conducted on a property in the municipality of Jaboatão dos Guararapes in the metropolitan region of Recife, state of Pernambuco, Brazil. Epidemiological data were obtained from the owner of the affected herd. Twenty-eight sheep were reared on the farm; eight of them were suckling lambs between seven and 40 days of age, presenting neurological signs. These and the adult other sheep were evaluated clinically. The method described by Radostits et al. (15) was used for the assessment of the general clinical condition. The HeadRaising test (HR test) and the Stand-Up test were performed to assess the neurological status of the animals. The HR test consists of raising the animal's head, forcing it backward in the caudal direction for one minute and releasing it suddenly to check for a loss of balance (14). The Stand-Up test consists of holding the animal in lateral decubitus for one minute and then releasing it to determine whether it has difficulty returning to the upright position (9).

Blood samples were collected from the jugular vein for the hematological evaluation of clinically affected animals. One lamb died spontaneously and was necropsied. Samples collected from organs of the thoracic and abdominal cavities and central nervous system were fixed in $10 \%$ formalin, routinely processed for histology, embedded in paraffin, sectioned at $5 \mu \mathrm{m}$ thickness in slides, stained with hematoxylin and eosin (HE) and examined under a light microscope. The field to which the adult animals had access was also inspected to determine the composition of plants.

The property on which the outbreak occurred had an area of approximately 1 ha and was used for the semiextensive rearing of Dorper sheep. Adult animals were released into an area with malformed grass early in the morning and were collected at the end of the afternoon, when they received a commercial ration and crushed Brachiaria spp. During the general clinical assessment, $60 \%[12 / 20]$ of the lactating ewe presented engorged episcleral vessels and tachypneia, but no postural abnormalities were observed during or after the HR test and Stand-Up test. The inspection of the grazing areas (Fig. 1) revealed the occurrence of I. asarifolia and some plants had evidence of having been consumed (Fig. 2). No hematological abnormalities were found in the adult sheep.

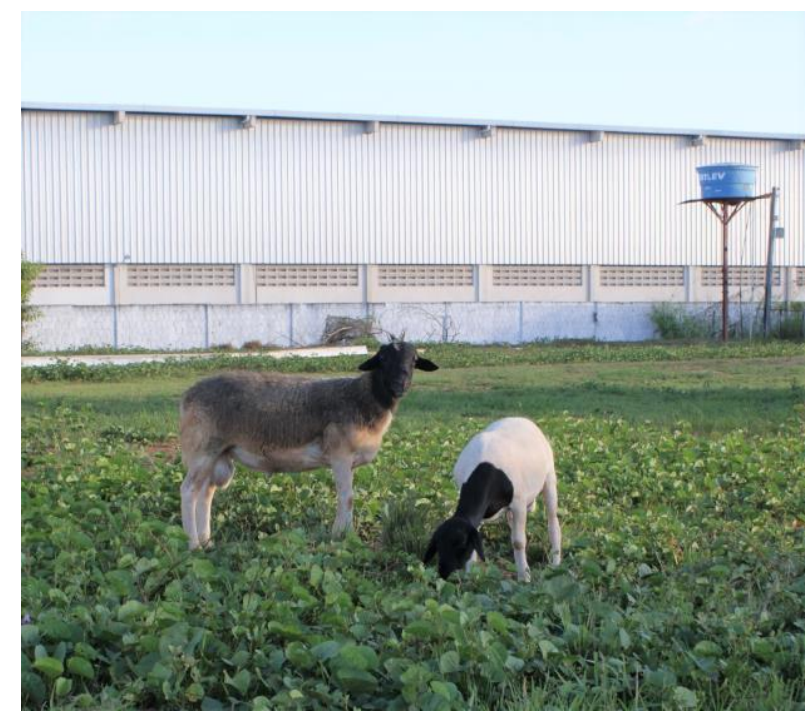

Figure 1. Adult sheep eating Ipomoea asarifolia, Jaboatão dos Guararapes, PE, Brazil.

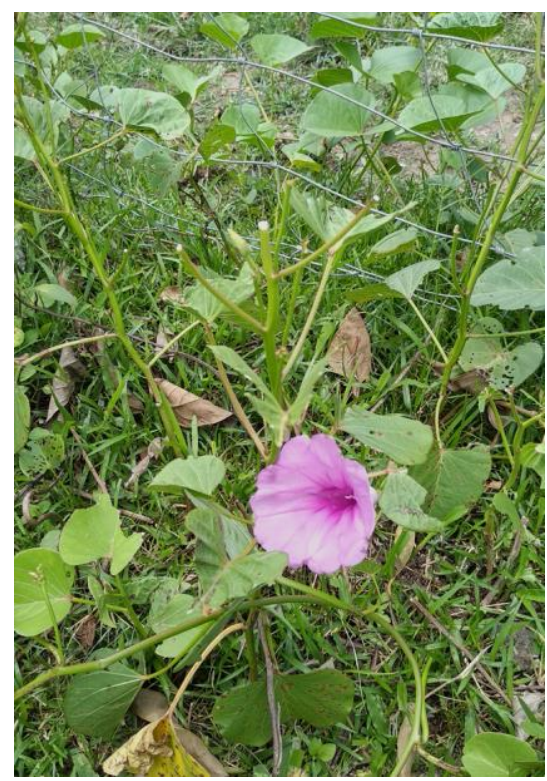

Figure 2. Ipomoea asarifolia with signs of consumption by animals.

The lambs were reared in a separate stall from adult animals without access to the grass with I. asarifolia. These animals received milk from their mothers four times a day. The milk was obtained individually from each lactating ewe, blended and subsequently provided to the lambs in buckets. All suckling lambs in the herd became ill [8/8]. During the clinical examinations, 37.5\% [3/8] presented head and neck tremors, dysmetria mainly in the hind limbs, a wide-based stance, lateral gait, abnormal posture and imbalance followed by falls (Fig. 3). These signs became more evident when the animals were forced to move. Moreover, 30-day-old lamb presented generalized tremors, difficulty ingesting milk, dehydration, weight loss and permanent decubitus, dying death two weeks after the onset of the clinical signs. 


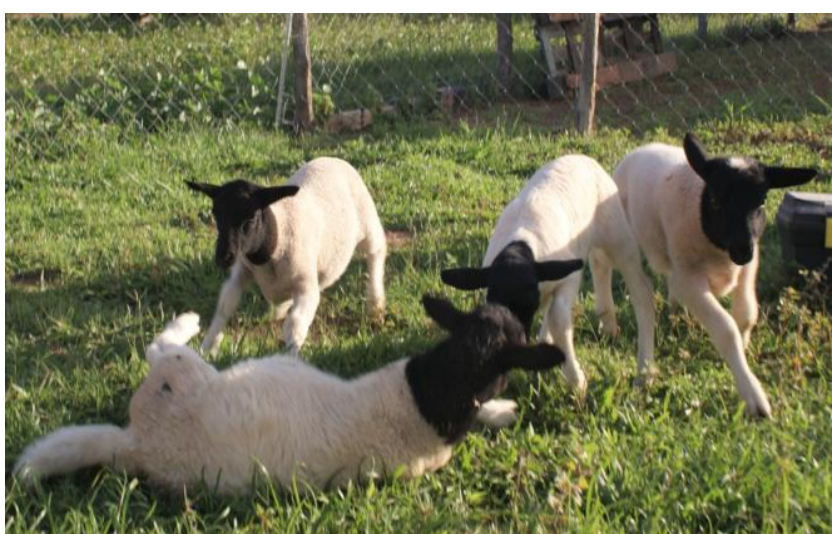

Figure 3. Lambs showing staggering gait, falls in unusual positions and difficulty returning to upright position.

All lambs submitted to HR and Stand-Up tests presented incoordination, fell immediately after performing the procedures and had head tremors and a wide-based stance for five minutes. These signs were no longer evident when the animals were at rest. No hematological abnormalities were found in the lambs.

No gross alterations were found. The histological findings consisted of axonal spheroids in the cerebellum granular layer as well as numerous eosinophilic and necrotic neurons in the cerebral cortex and cerebellum molecular layer (Fig. 4).

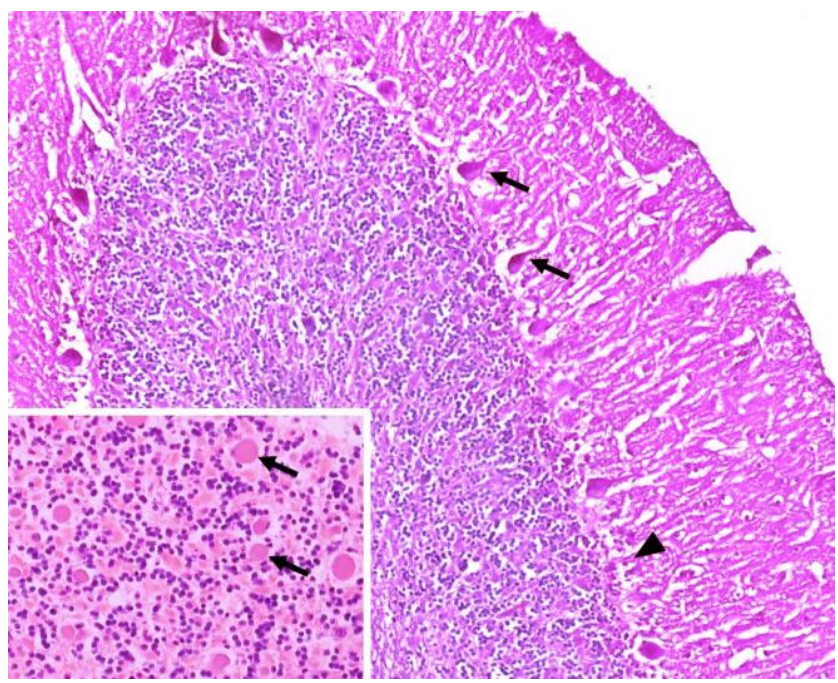

Figure 4. Photomicrograph of cerebellum of lamb poisoned by tremorgenic toxin through milk. Eosinophilic and necrotic Purkinje neurons (arrow) and areas in which Purkinje cells are missing (arrowhead). HE, magnification: 10x. Inset: Axonal spheroids in the granular layer (arrow). HE, magnification: 40x.

The adult sheep were denied access to the grazing area invaded by $I$. asarifolia, exclusively receiving a commercial ration and Brachiaria spp. provided in the trough. The lambs were weaned and observed daily for the evolution of the disease. Progressive clinical improvement was found until complete recovery by the $14^{\text {th }}$ day of observation. The lambs remained without neurological signs even when movement was stimulated.

\section{Discussion}

The diagnosis of poisoning by I. asarifolia was based on the epidemiological and clinical aspects, histopathological findings and confirmation of the massive presence of $I$. asarifolia in the grazing area, which had evidence of consumption. Studies with sheep and rodents have shown that the toxic component of I. asarifolia is eliminated through milk (12), as the offspring of lactating mice that ingested $20 \%$ to $30 \%$ I. asarifolia in the ration exhibited tremors two to four days after birth (10). In the outbreak described herein, all suckling lambs presented clinical signs, probably due to the fact that the farmer blended all milk obtained from milking before offering it to the lambs. Therefore, all suckling lambs were exposed to the toxin eliminated from the mothers through the milk.

The ewes exhibited no neurological clinical signs. This aspect of poisoning by $I$. asarifolia was also reproduced in rats in an experimental study in which nursing offspring presented muscle tremors, whereas their lactating mothers did not (19). This result shows a dosedependent relationship between neurological clinical signs and the intake of I. asarifolia (19).

The clinical signs observed in poisoned lambs were similar to those reported in other studies of poisoning by I. asarifolia in adult animals, such as mild tremors of the head and neck muscles that progressed to uncoordinated gait, hypermetria and a wide-based stance. When stimulated to move, the animals present severely uncoordinated movements, staggering gait and falls, sometimes in unusual positions, with the occurrence of death in more severe cases of poisoning $(2,4,12,16)$.

Gross and histological lesions are rare or scarce and occur most often in animals with a long clinical course. In such cases, cerebellar lesions, the degeneration and loss of Purkinje cells and axonal spheroids in the granular layer of the cerebellum may be noted $(2,13,16)$.

Clinical signs, such as head tremors, ataxia and difficulty standing, are similar to signs related to poisoning by other species of Ipomoea that cause lysosomal storage disease (LSD). However, swainsonine, which is the alkaloid that causes LSD, is found in an insufficient quantity $(\geq 0.001 \%)$ in I. asarifolia (13) to cause the disease. An important finding is the absence of histological lesions resulting from the accumulation of incompletely processed oligosaccharides, which is characteristic of the consumption of plants containing swainsonine $(2,9)$.

The components that cause tremorgenic syndrome associated with the consumption of I. asarifolia are indolediterpenes produced by the symbiotic fungi Clavicipitaceous and Periglandula $(8,11,18,19)$. Some of the pure compounds belonging to this class have demonstrated a tremorgenic effect on mice $(6,19)$. As 
there is no specific treatment for the neutralization of tremorgenic toxins, the recommendation is to remove affected animals from areas invaded by the plant, since sheep can fully recover from seven to 21 days after the onset of the first clinical signs (2).

In conclusion, ewes that consume I. asarifolia during lactation can poison their lambs by transferring the toxin through the milk and younger animals are more susceptible to poisoning than adults, since only suckling lambs presented neurological clinical signs in the present study.

\section{Acknowledgments}

The authors are grateful to the Brazilian fostering agencies FACEPE (process number: APQ-0202- 5.05/17), CAPES (Financing code: 001) and CNPq (process number: 304804/2018-5) for providing funding for the development of this study.

\section{References}

1. Araújo JAS, Riet-Correa F, Medeiros RMT, Soares MP, Oliveira DM, Carvalho FKL. Intoxicação experimental por Ipomoea asarifolia (Convolvulaceae) em caprinos e ovinos. Pesq Vet Bras. 2008;28:488-94.

2. Barbosa JD, Oliveira CMC, Duarte MD, Peixoto PV, Tokarnia CH. Intoxicações experimental e natural por Ipomoea asarifolia (Convolvulaceae) em búfalos e outros ruminantes. Pesq Vet Bras. 2005;25:231-34.

3. Carvalho FKL, Dantas AFM, Riet-Correa F, Pires JPS, Silva FOR. Intoxicação por Ipomoea asarifolia em bovinos e ovinos no Rio Grande do Norte. Pesq Vet Bras. 2014;34:1073-76.

4. Döbereiner J, Tokarnia CH, Canela CFC. Intoxicação experimental pela salsa (Ipomoea asarifolia R. et Schult.) em ruminantes. Arqs Inst Biol Animal. 1960;3:39-57.

5. Freitas FJC, Lima JM, Gameleira JS, Costa ALF, Câmara ACL, Soto-Blanco B. Surtos de intoxicação por Ipomoea asarifolia (salsa) em cordeiros e cabritos lactentes. Vet Zootec. 2011;18:548-51.

6. Gardner DR, Welch KD, Lee ST, Cook D, Riet-Correa F. Tremorgenic Indole Diterpenes from Ipomoea asarifolia and Ipomoea muelleri and the Identification of 6,7-Dehydro-11-hydroxy-12,13-epoxyterpendole A. J Nat Prod. 2018;81(7):1682-86.

7. Guedes KMR, Riet-Correa F, Dantas AFM, Simões SVD, Miranda Neto EG, Nobre VMT, Medeiros RMT. Doenças do sistema nervoso central em caprinos e ovinos no semi-árido. Pesq Vet Bras. 2007;27:29-38.

8. Lee ST, Gardner DR, Cook D. Identification of indole diterpenes in Ipomoea asarifolia and Ipomoea muelleri, plants tremorgenic to livestock. J Agric Food Chem. 2017;65(26):5266-77.
9. Lima DDCC, Albuquerque RF, Rocha BP, Barros MEG, Gardner DR, Medeiros RM, Riet-Correa F, Mendonça FS. Doença de depósito lisossomal induzida pelo consumo de Ipomoea verbascoidea (Convolvulaceae) em caprinos no semiárido de Pernambuco. Pesq Vet Bras. 2013;33(7):867-72.

10. Lopes JRG, Riet-Correa F, Medeiros MA, Dantas FPM, Medeiros RMT. Administração de diferentes concentrações de folhas de Ipomoea asarifolia na ração de camundongos. Cienc Rural. 2014;44:872-77.

11. Lopes JRG, Riet-Correa F, Medeiros RMT. Phytotoxins eliminated by milk: a review. Pesq Vet Bras. 2019;39(4):231-7.

12. Lucena KFC, Rodrigues JMN, Campos EM, Dantas AFM, Pfister JA, Cook D, Medeiros RMT, RietCorrea F. Poisoning by Ipomoea asarifolia in lambs by the ingestion of milk from ewes that ingest the plant. Toxicon. 2014;92:129-32.

13. Medeiros RMT, Barbosa RC, Riet-Correa F, Lima EF, Tabosa IM, Barros SS, Gardner DR, Molyneux RJ. Tremorgenic syndrome in goats caused by Ipomoea asarifolia in northeastern Brasil. Toxicon 2003;41:933-5.

14. Pienaar JG, Kellerman TS, Basson PA, Jenkins WL, Vahrmeijer J. Maldronksiekte in cattle: a neuronopathy caused by Solanum kwebense N.E. Br. Onderstepoort J Vet Res. 1976;43:67-74.

15. Radostits OM, Gay CC, Blood DC, Hinchcliff KW. Clínica Veterinária: Um Tratado de Doenças de Bovinos, Ovinos, Suínos, Caprinos e Eqüinos. Rio de Janeiro: Guanabara Koogan; 2002, 1737p.

16. Riet-Correa F, Medeiros RMT, Pfister JA, Mendonça FS. Toxic plants affecting the nervous system of ruminants and horses in Brazil. Pesq Vet Bras. 2017;37(12):1357-68.

17. Riet-Correa F, Rivero R, Odriozola E, Adrien MDL, Medeiros RM, Schild A.L. 2013. Mycotoxicoses of ruminants and horses. $\mathrm{J}$ Vet Diagn Invest. 2013;25(6):692-708.

18. Schardl CL, Young CA, Hesse U, Amyotte SG, Andreeva K, Calie PJ, Fleetwood DJ, Haws DC, Moore N, Oeser B, Panaccione DG, Schweri KK, Voisey CR, Farman ML, Jaromczyk J W, Roe BA, O'Sullivan DM, Scott B, Tudzynski P, An Z, Arnaoudova EG, Bullock CT, Charlton ND, Chen L, Cox M, Dinkins RD, Florea S, Glenn AE, Gordon A, Güldener U, Harris DR, Hollin W, Jaromczyk J, Johnson RD, Khan AK, Leistner E, Leuchtmann A, Li C, Liu JG, Liu J, Liu M, Mace W, Machado C, Nagabhyru P, Pan J, Schmid J, Sugawara K, Steiner U, Takach JE, Tanaka E, Webb JS, Wilson EV, Wiseman JL, Yoshida R, Zeng Z. Plant-symbiotic fungi as chemical engineers: multi-genome analysis of the Clavicipitaceae reveals dynamics of alkaloid loci. PLoS Genetics. 2013;9(2):e1003323.

19. Welch KD, Pfister JA, Cook D, dos Santos FC, Lee S.T. Assessment of endophyte-derived tremorgenic 
compounds in Ipomoea asarifolia using mouse models. Toxicon. 2018;156:52-60. 